\title{
IMPACT OF CALCIUM PHOSPHATE ON SURVIVAL, INFECTIVITY AND PENETRATION OF ENTOMOPATHOGENIC NEMATODE, HETERORHABDITIS SPP. ISOLATED FROM EGYPT
}

\author{
AZAZY, A.M. ${ }^{1}$, SABRENAL. H. EL HAMOULY ${ }^{2}$, NAEMA. S. YEHIA ${ }^{2}$ and \\ ASMAA M. A. EL GAMAL ${ }^{1}$ \\ 1. Plant Protection Institute research, ARC, Dokki Giza \\ 2. Faculty of Science Minufiya University
}

(Manuscript received 17 November 2011)

\begin{abstract}
Exposure of Calcium phosphate affected the entomopathogenic nematode Heterorhabditis sp. differently. Survival, infectivity and penetration efficiency of Heterorhabditis sp. ((HPS1, HPS2 and HPS3) were affected by Calcium phosphate. At medium concentration (1M) of Calcium phosphate the affect on survival of Heterorhabditis sp (HPS1, HPS2 and HPS3) were 68.3, 30.2 and $33.5 \%$, respectively. Calcium phosphate $(0.2 \mathrm{M}$ and $2 \mathrm{M})$ were less effective on survival of the three nematode strains (8.02to12.2\%) and $(2.02$ to $14.6 \%)$, respectively. Entomopathogenic nematodes (HPS2) when used alone or mixed by low concentration (0.2M) unaffected on infectivity of Galleria mellonella (100\%), but medium concentration affected the infectivity of $G$. mellonella. The penetration rate of nematode alone was better than from the nematode mixed with Calcium phosphate. Calcium phosphate at three concentrations also reduced the penetration efficiency of nematodes (HPS1, HPS2 and HPS3) (29.8, 32.7 and 27.9\%) for three concentrations, respectively.

Key words: Calcium phosphate, Entomopathogenic nematodes, Infectivity, Penetration, Survival.
\end{abstract}

\section{INTRODUCTION}

Entomopathogenic nematodes of the families Steinernematidae and Heterorhabditdae have considerable potential for biological control of insect pests and have been recovered from soil in many parts of the world (Kaya \& Gaugler, 1993). Isolation of entomopathogenic nematodes are more commonly found in sandy to loamy soils than in clay soils, but data have not included soil salinity (Blackshaw, 1988, Glazer et. al., 1991, Hara et. al., 1991, Hominick, \& Briscoe, 1990, Roman \& Beavers, 1983). However, the mechanisms of osmoregulation among Steinernematids and Heterorhabditis are not known, although studies have demonstrated their capability to withstand osmotic stress (Thurston et. al., 1994, Glazer \& Salame, 2000).The reproduction, development, dispersal and infectivity of entomopathogenic nematodes are known to be affected by environmental temperature (Grewal et. al., 1994, Griffin, 1993). Many classes of soil amendments including mineral fertilizers, chemical and biorational pesticides as well as organic manures are regularly applied to the soil 
during the growing season of a given crop. On the other hand, potential interaction whether antagonistic or synergistic with soil amendments is the key for successful biological control with entomopathogenic nematodes (Forschler et. al., 1990). Finally, nematodes may be combined with other control agents to achieve better control of a single pest through additive or preferably, synergistic effects on pest mortality. The types of interactions between nematodes and other agents may range from effects on control agent viability and /or pathogenicity, control agent recycling in the target pest, and effects on pest susceptibility to the control agents (KoppenhÖfer and Grewal, 2005). This investigation aimed at determining the effect of calcium phosphate on survival, penetration and pathogenicity of Heterorhabditids sp entomopathogenic nematodes.

\section{MATERIALS AND METHODS}

1- Three isolates of Heterorhabditis sp. (HPS1, HPS2 and HPS3) collected from different locations of Egypt were reared on larvae of the greater wax moth, Galleria mellonella at $25^{\circ} \mathrm{C}$. The infective juveniles (IJs) were washed and used within one week of harvesting.

2- Preparation of the tested samples:

Calcium phosphate salt (HAP) was prepared and then tested with entomopathogenic nematode as the following.

\section{Survival test:}

The effect of Calcium phosphate at different concentration (high (2M), medium $(1 \mathrm{M})$ and low $(0.2 \mathrm{M})$ ) had been tested on the survival of entomopathogenic nematodes at $25^{\circ} \mathrm{C} \pm 1$. The test was performed as the following. Four Petri dishes of each tested species for each concentration where every Petri dish containing $20 \mathrm{ml}$ of nematode (each $1 \mathrm{ml}$ containing approximately 1000 infective juveniles) and Calcium phosphate. And five Petri dishes for control (each containing $20 \mathrm{ml}$ of nematode + distilled water). Such dead and/or live IJs were determined after 2, 3, 4 and 7 day by dissecting microscope.

\section{Infectivity test:}

The test was performed as the following. Four Petri dishes for each time, every one contained $60 \mathrm{~g}$ soil $+6 \mathrm{ml}$ nematode solution + Calcium phosphate(three concentrations), and 4 Petri dishes for control at each time. Four G. mellonella larvae were added to each Petri dish, and these dishes were kept at $25^{\circ} \mathrm{C}, 31^{\circ} \mathrm{C}$ for (zero time, $1 \mathrm{~h}, 2 \mathrm{~h}$ and $3 \mathrm{~h})$. Mortality records were taken after 5 days and corrected according to Abbott's formula (Abbott, 1925). 


\section{Penetration Rate:}

To determine the ability of Heterorhabditids sp. (HPS1, HPS2 and HPS3) if Calcium phosphate affect to penetrate into a susceptible insect host, the penetration efficiency of nematodes stored in Calcium phosphate at $25^{\circ} \mathrm{C}$ for 7 days was assessed. The nematodes used in this experiment were stored in the three concentrations (low, mid and high) of Calcium phosphate or alone at nematode densities of $1,000 \mathrm{IJs} / \mathrm{ml}$ Heterorhabditids sp. (HPS1, HPS2 and HPS3). G. mellonella larvae were exposed to freshly emerged nematode infection, at a dose level of $20 \mathrm{IJs} / \mathrm{larva}$ in $300 \mu \mathrm{l}$ of distilled water in $1.5 \mathrm{ml}$ Eppendorf tubes, lined with double layer filter paper (Whatman No. 1) and kept at $25^{\circ} \mathrm{C}$, in the dark. After 5days of exposure, at least 10 dead larvae were washed twice by distilled water to remove any nematode juveniles that attached to them, dried and dissected under a stereomicroscope. Nematode numbers inside each larva was counted and the penetration rate was calculated as an average.

The significance of the main effects was determined by analysis of variance (ANOVA).The significance of various treatments was evaluated by Duncan's multiple range test $(P=0.05)$ (Colman, 2001) according to the statistical methods of Snedecor (1956). All analyses were made using a software package "Costat", a product of Cohort Software Inc., Berkeley, California

\section{RESULTS AND DISCUSSION}

(I) Survival of Heterorhabditids sp. infective juveniles in different concentrations of Calcium phosphate:

Data in table (1) shows mortality percentages of IJs of Heterorhabditids sp. at two and three days after treatment. It was found that, two days after treatment, the majority of infective juveniles were capable of survival at all concentrations except at the medium concentration since mortality was more increased than at low and high concentration the mortality was less increased.

It was found that, two day after treatment, the majority of entomopathogenic nematodes were capable of survival at all the concentration.

General means of nematode strains mortality percentages at 2 and 3 days, after treatment were $7.4(9.8), 7(10)$ and 7.8 (11) \%, respectively. Statistical analysis indicated that there was high significant differences among the three concentrations tested $(\mathrm{df}=2, \mathrm{~F}=82.4, \mathrm{P}=0.0000)$ at $2^{\text {nd }}$ day and $(\mathrm{df}=2, \mathrm{~F}=273.2, \mathrm{P}=0.0000)$ at $3^{\text {rd }}$ day after treatment. On the other hand, no significant differences were found among nematodes strains at $2^{\text {nd }}$ and $3^{\text {rd }}$ day. All interactions effects also, among the different 
treatments were insignificant at 3 days, but significant differences was found between treatments (concentration and Infective juveniles) ( $d f=4, F=2.9, P=0.0334)$.

Data in table (2) indicated that at (1M), percent mortality rates of Heterorhabditids sp. (HPS1, HPS2 and HPS3) after four days of treatment were 27.7, 28.9 and 29.3 respectively. These values were obviously increased to $68.3,30.2$ and 33.5 respectively after $7^{\text {th }}$ day of exposure. As the concentration increased to (2M), the parallel after 4and 7 days were increased to 1.23(4.9), 2.02(2.02), and 3.6(14.6) $\%$ respectively. On the other hand, low concentration achieved mortality of IJs after 4 days and 7days of exposure were 65.7(12.2), 7.9 (8.02)and 8.9(11.7)\% respectively.

Considering general means of the three concentrations of the three nematode strains, it was found that $11.6,13.4$ and $15.3 \%$ of IJs for HPS1, HPS2 and HPS3 were killed after 4 days of exposure. These values were markedly increased to $28.3,13$ and $18.5 \%$, respectively after 7 days. Also the trend of nematode strains sensitivity to Calcium phosphate was detected. Since, HPS1 was the most sensitive species, followed by HPS3, while HPS2 juveniles were the most tolerant strain. Statistical analysis, showed highly significant differences between the three concentration treated $(\mathrm{df}=2, \mathrm{~F}=284, \mathrm{P}=0.0000)$ at 4days and $(\mathrm{df}=2, \mathrm{~F}=191.9, \mathrm{P}=0.0000)$ at 7days after treatment. Also, significant differences were found among three entomopathogenic nematode strains treated $(\mathrm{df}=2, \mathrm{~F}=4.6, \mathrm{P}=0.0164)$ at 4 days and highly significant difference $(\mathrm{df}=2, \mathrm{~F}=31.7, \mathrm{P}=0.0000)$ at 7days after exposure. All interaction effects also, among the different treatment were no significant at 4days ( $d f=4, \quad F=0.3, P=0.8595$ ) but it found highly significant differences between treatments ( $d f=4, F=32.4, P=0.0000)$. Regarding to data, the highly percentage mortality rates of nematode resulted from the application of Calcium phosphate (1M), it could be due to that this concentration of the salt caused some harm to the nematode cuticle. Increased efforts in recent years have been focused on biological control using entomopathogenic nematode (IJs) of the families of Steinernematidae and Heterorhabditidae as pest control agents. On the other hand, these nematodes are often applied to soil that regularly treated with fertilizers, insecticides and pesticides. Therefore, many most of these studies showed that nematodes are compatible with many mineral fertilizers even to the extent of benign tank mixed or applied to soil that regularly. Nitrogen, Phosphorus and Potassium (NPK) fertilizers and potassium nitrate suppressed nematode infectivity and reproduction (Bednarek and Gaugler, 1999). This study is the first study on the effect of Calcium phosphate on the entomopathogenic nematodes which acts as (biological agent) all the previous studies utilized the harmful effect on bacteria and fungi (Kajak et. al. Heterorhabditids sp., 1991, Shapiro et. al., 1996). 
Table 1. Effect of different concentrations of Calcium phosphate on mortality percentages of Heterorhabditids sp. (HPS1, HPS2, HPS3) after 2 and 3 days of treatment.

\begin{tabular}{|c|c|c|c|c|c|c|c|c|}
\hline \multirow{3}{*}{ Concentrations } & \multicolumn{8}{|c|}{ \%Mortality } \\
\hline & \multicolumn{3}{|c|}{ 2- days } & \multirow{2}{*}{$\begin{array}{c}\text { General } \\
\text { mean }\end{array}$} & \multicolumn{3}{|c|}{ 3- days } & \multirow{2}{*}{$\begin{array}{c}\text { General } \\
\text { mean }\end{array}$} \\
\hline & HPS1 & HPS2 & HPS3 & & HPS1 & HPS2 & HPS3 & \\
\hline $\operatorname{High}(2 \mathrm{M})$ & 1.5 & 3.3 & 3.4 & $2.7 \mathrm{~b}$ & 2.2 & 1.9 & 1.9 & $2 b$ \\
\hline medium (1 M) & 18.2 & 13 & 14.7 & $15.3 a$ & 23 & 21.6 & 24.1 & $22.9 \mathrm{a}$ \\
\hline Low $(0.2 \mathrm{M})$ & 2.4 & 4.8 & 5.4 & $4.2 \mathrm{~b}$ & 4.05 & 6.4 & 17.14 & $5.9 \mathrm{~b}$ \\
\hline General Mean & $7.4 \mathrm{a}$ & $7 \mathrm{a}$ & $7.8 \mathrm{a}$ & & $9.8 \mathrm{a}$ & $10 \mathrm{a}$ & $11 \mathrm{a}$ & \\
\hline
\end{tabular}

Table 2. Effect of different concentrations of Calcium phosphate on mortality percentages of Heterorhabditids sp. (HPS1, HPS2, HPS3) after 4 and 7 days of treatment.

\begin{tabular}{|c|c|c|c|c|c|c|c|c|}
\hline \multirow{3}{*}{ Concentrations } & \multicolumn{8}{|c|}{ \%Mortality } \\
\hline & \multicolumn{3}{|c|}{ 4- days } & \multirow{2}{*}{$\begin{array}{c}\text { General } \\
\text { mean }\end{array}$} & \multicolumn{3}{|c|}{ 7- days } & \multirow{2}{*}{$\begin{array}{c}\text { General } \\
\text { mean }\end{array}$} \\
\hline & HPs1 & HPs2 & HPs3 & & HPs1 & HPs2 & HPs3 & \\
\hline $\operatorname{High}(2 \mathrm{M})$ & 3.2 & 2.02 & 3.6 & $2.9 \mathrm{c}$ & 4.92 & 2.02 & 14.6 & $7.2 \mathrm{~b}$ \\
\hline medium (1 M) & 27.7 & 28.9 & 29.3 & $28.6 \mathrm{a}$ & 68.3 & 30.2 & 33.5 & $44 a$ \\
\hline Low $(0.2 \mathrm{M})$ & 5.72 & 7.93 & 8.9 & $7.52 \mathrm{~b}$ & 12.2 & 8.02 & 11.7 & $10.6 \mathrm{~b}$ \\
\hline General Mean & $\begin{array}{c}11.6 \\
b\end{array}$ & $\begin{array}{c}13.4 \\
a b\end{array}$ & $\begin{array}{c}15.3 \\
a \\
\end{array}$ & & $\begin{array}{c}28.5 \\
a \\
\end{array}$ & $13 c$ & $\begin{array}{c}18.5 \\
b\end{array}$ & \\
\hline
\end{tabular}

(II) Infectivity test:

Effect of two concentrations from Calcium phosphate on the infectivity of nematode strain, Heterorhabditids sp. (HPS2) against Galleria mellonella at $25^{\circ} \mathrm{C}$ and $31^{\circ} \mathrm{C}$ for the interval times $(0,1,2$ and 3 hours) in the soil.

Entomopathogenic nematodes are used for the biological control of soilinhabiting insects of turfgrass, ornamentals, mushrooms, artichokes, citrus, cranberries and apples. The addition of organic soil amendments to improve soil fertility and plant growth is among the oldest of agricultural practices. Therefore, the objectives of these studies are to determine the effects of an inorganic compound (Calcium phosphate) on infectivity of entomopathogenic nematode Heterorhabditids sp. (HPS2) under laboratory conditions. 
Data in ( figure, 1) showed that the using entomopathogenic nematode HPS2 against $G$. mellonella alone or mixed with the lower concentration ( $0.2 \mathrm{M}$ ) of Calcium phosphate gave $100 \%$ mortality at $25^{\circ} \mathrm{C}$ and $31^{\circ} \mathrm{C}$ for the four interval times $(0,1,2$ and 3hours). But as seen in Fig( 2) data showed clearly that HPS2 alone caused $100 \%$ mortality of $G$. mellonella , when mixed with the mid concentration ( $1 \mathrm{M}$ ) affected the nematode ability to kill $G$. mellonella at $25^{\circ} \mathrm{C}$ for the interval times $(0,1,2$ and 3hours).when they mixed gave a slight increase $6.9 \%$ mortality of $G$. mellonella at $31^{\circ} \mathrm{C}$ for the interval time (2hours) in the soil. Generally, the mixing of entomopathogenic nematodes with the lower concentration of Calcium phosphate had no effect on infectivity on $G$. mellonella, but when mixed with the mid concentration of Calcium phosphate the infectivity of $G$. mellonella affected. Bednarek \& Gaugler (1979) and Shapiro et. al., 1996, suggested that the populations of Steinernema feltiae were influenced by densities of host populations rather than antagonists. The positive response of many populations of soil inhabiting insects to manure is well established among them potential hosts of entomopathogenic nematodes Kajak et. al., 1991. Nevertheless, manure applications did not protect $S$. feltiae populations from decline when the applications were accompanied by inorganic fertilizer treatments. The fresh manure reduced $S$. carpocapsae virulence in 60-day field tests, whereas composted manure was not harmful. These authors hypothesized that this detrimental effect may have been attribute to decomposition of fresh manure leading to reduced oxygen availability Shapiro et. al., 1996.

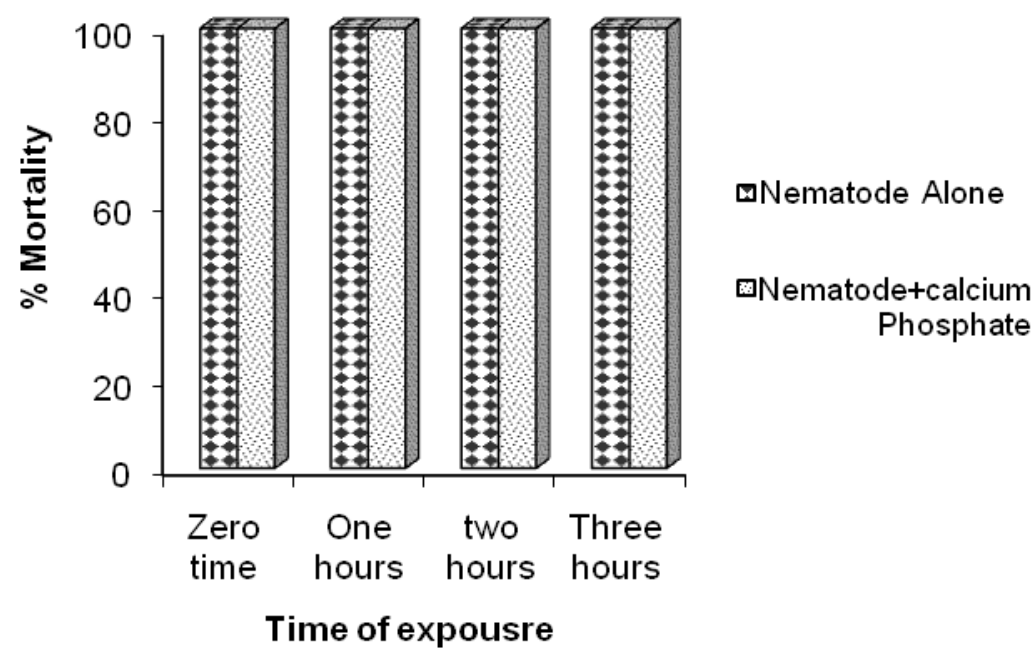

Figure 1. Infectivity of Heterorhabditis sp. (HPS2) juveniles to Galleria mellonella after treatment with low concentration(0.2M) of Calcium phosphate at $25^{\circ} \mathrm{C}$ and $31^{\circ} \mathrm{C}$ in the soil. 

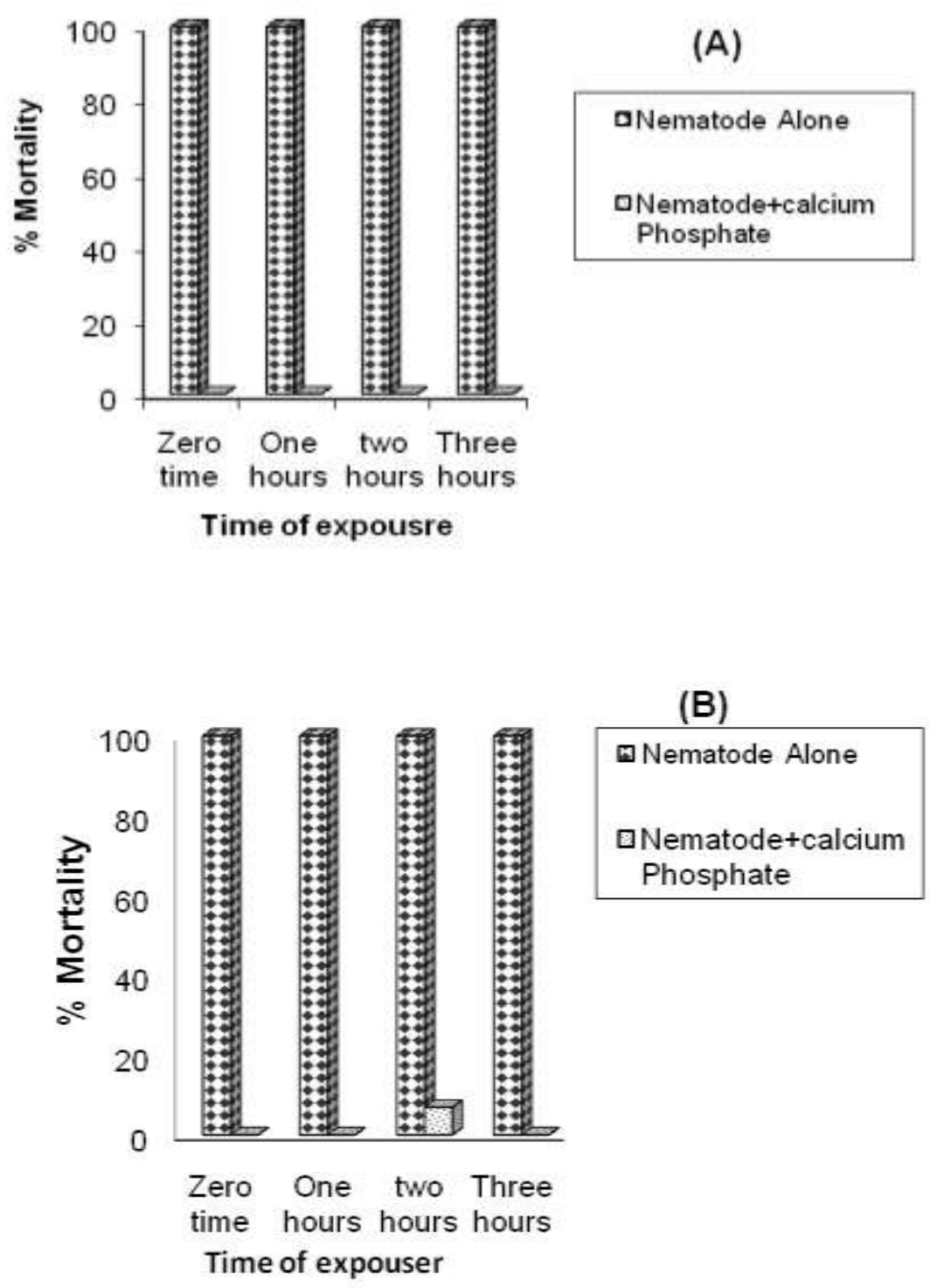

Figure 2. Infectivity of Heterorhabditis sp. (HPS2) juveniles to Galleria mellonella after treatment with mid concentration (1M) of Calcium phosphate at $25^{\circ} \mathrm{C}$ (A) and $31^{\circ} \mathrm{C}(\mathrm{B})$ in the soil.

III. Nematode penetration efficiency in different concentrations of Calcium phosphate: Fig. (3) exhibit that the highest penetration rate of nematode alone $54 \%$ was found in dead $G$. mellonella larvae infected with HPS2. The data proved that the penetration rate of nematode alone was better than from mixing the nematode with Calcium phosphate. Calcium phosphate at the three concentrations also reduced the penetration efficiency of three nematodes (HPS1, HPS2 and HPS3) (29.8, 32.7 and $27.9 \%$ ) for three concentrations, respectively. Statistical analysis, showed that there 
were highly significant differences between the three concentrations of Calcium phosphate ( $d f=3 F=25.4 P=.0000)$ and no significant differences between the three nematode strains ( $\mathrm{df}=2 \mathrm{~F}=0.89 \mathrm{P}=.4241$ ). The interaction between nematode isolates and concentrations was also significant ( $\mathrm{df}=6 \mathrm{~F}=3.22 \mathrm{P}=.0184$ ). Thurston et. al., (1994) said that, exposure to $\mathrm{NaCl}, \mathrm{KCI}$, and $\mathrm{CaCl}_{2}$ affected the entomopathogenic nematodes Heterorhabditis bacteriophora and Steinernema glaseri differently. Survival, virulence, and penetration efficiency of $S$. glaseri were not affected by these salts. Calcium chloride and $\mathrm{KCI}$ had no effect on $H$. bacteriophora survival, penetration efficiency. $\mathrm{NaC1}$, however, adversely affected each of these parameters at high salinities (>16 dS/m).

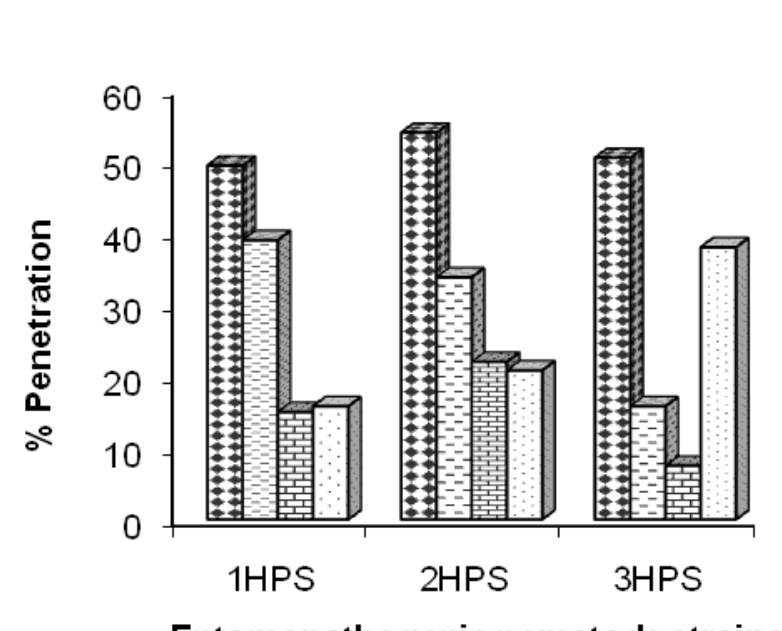

GNematode alone

Elow Nematode+Calcium

巴Mid Nematode+Calcium

口High Nematode+Calcium

Entomopathogenic nematode strains

Figure 4. Mean penetration rate of entomopathogenic nematodes storage in three concentrations of Calcium phosphate solutions at $25^{\circ} \mathrm{C}$ for 7 days. 


\section{REFERENCES}

1. Abbott, W. S. 1925. "A method of computing the effectiveness of an insecticide." J. Econ. Entomol. 18: 265-267.

2. Bednarek, A. and R. Gaugler. 1997. Compatibility of soil amendments with entomopathogenic nematodes. J. Nematol. , 29(2):220 -227.

3. Blackshaw, R.P. 1988. A survey of insect parasitic nematodes in Northern Ireland. Ann. Appl. Biol., 113: 561-565.

4. Colman, A.M. 2001. Dunan's multiple range test. Dictionary of Psychology. Publ Oxford University.

5. Forschler, B. T., J. N. All and W. A. Gardner. 1990. Steinernema feltiae activity and infectivity in response to herbicide exposure in aqueous and soil environments. J. Invertebr. Pathol. , 55(3):375-379.

6. Glazer I. and L. Salame. 2000. Osmotic survival of the entomopathogenic nematode Steinernema carpocapsae. Biological control 18:251-257

7. Grewal, P.S., S. Selvan. and R. Gaugler. 1994. Thermal adaptation of entomopathogenic nematodes: niche breadth for infection, establishment and reproduction J. Thermal. Biol., 19: 245-253.

8. Griffin, C.T. 1993. Temperature responses of entomopathogenic nematodes: Implications for the success of biological control programmes. In: Bedding RAR, Kaya $\mathrm{H}$ (eds) Nematodes and the biological control of insect pests. CSIRO, East Melbourne, pp 115-126

9. Hara, A. H., Gaugler, R., H. K. Kaya and L. M. LeBeck. 1991. Natural populations of entomopathogenic Nematodes (Rhabditida: Heterorhabditidae, Steinernematidae) from the Hawaiian Islands. Environmetal Entomology, 20: 211216.

10. Hominick, W. M. and B. R. Briscoe. 1990. Occurrence of entomopathogenic nematodes (Rhabditida: Steinernematidae and Heterorhabdidae) in British soils. Parasitology, 100: 295-302.

11. Kajak, A., Chmielweski,. K., M. Kaczmarek and E. Rembiakowska. 1991. Experimental studies on the effective of epigenic predators on matter decomposition process in managed peat grasslands. Polish Ecological Studies, 17:289-310.

12. Kaya, H.K. and R. Gaugler. 1993. Entomopathogenic nematodes. Annual Review of Entomology, 38: 181-206. 
13. Koppenhöfer, A. M. and P. S. Grewal. 2005. Compatibility and interactions with agrochemicals and other biocontrol agents, In: Nematodes as Biocontrol Agents, pp. 363-381,CABI Publishing Wallingford, UK.

14. Roman, J. and J. B. Beavers. 1983. A survey of Puerto Rican soils for entomogenous nematodes which attack Diaprepes abbreviators (L.) Coloeoplera: Curculionidae). J. Agric. Uni. Puerto Rico, 1983: 311-316.

15. Snedecor, G.W. 1956. Statistical Methods. 5th Ed. Iowa State University College Press, Ames, Iowa, USA.

16. Thurston, G., Ni. Yansong and Harry, K. Kaya. 1994. Influence of salinity on survival and infectivity of entomopathogenic nematodes. J. Nematol. 26(3):345351 
تأثير فوسفات الكالسيوم على بقاء وعدوى و اخترلق عزلات مصرية من النيماتودا Heterorhabditis spp. الممرضة للحشرات

$$
\begin{aligned}
& \text { أحمد محمد عزازى } 1 \text { ، صبرنال الحامولى } 2 \text { ، نعيمة يحيى 22، أسماء الجمل1 } \\
& \text { 1-معهُ بحوث وقاية النباتات - مكز البحوث الزراعية - الدقى - جيزة } \\
& \text { 2- كلية العلوم جامعة المنوفية }
\end{aligned}
$$

تأثير فوسفات الكالسيوم على النيماتودا الممرضة للحشرات من حيث ( فترة البقاء و قدرتها

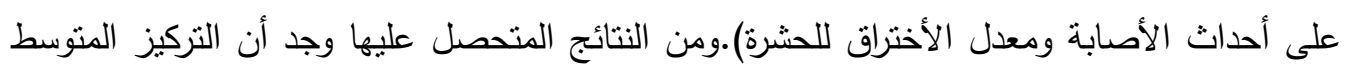

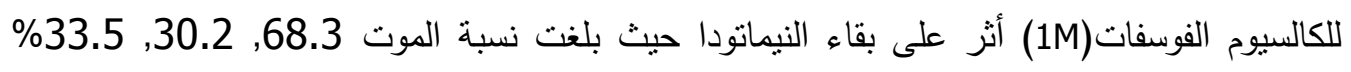
للأنواع (HPS1,HPS2andHPS3) على التوالى. ووجد أن التركيزان الأعلى و المنخفض كانا أقل نأثيرا

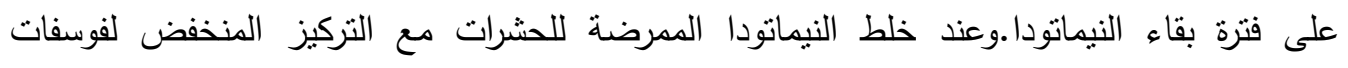

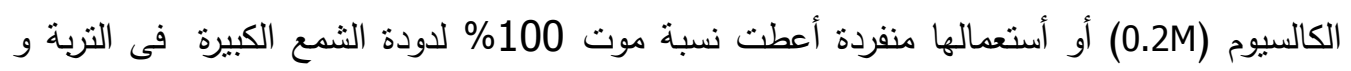

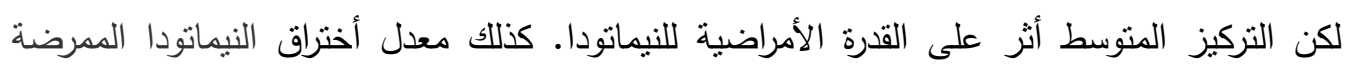

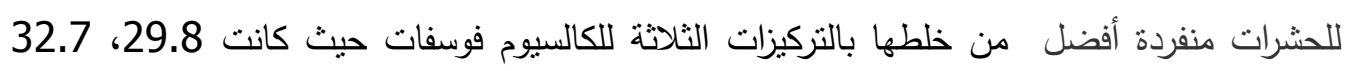
\%27.9, 